\title{
Comparative seed germination traits in bog and fen mire wetlands
}

\author{
Eduardo Fernández-Pascual ${ }^{1,2}$ \\ ${ }^{1}$ Comparative Plant and Fungal Biology, Royal Botanic Gardens, Kew, Wellcome Trust Millennium Building, Wakehurst \\ Place, Ardingly, West Sussex RH17 6TN, UK; ${ }^{2}$ Jardín Botánico Atlántico, Universidad de Oviedo, Avda. del Jardín \\ Botánico 2230, 33394 Gijón/Xixón, Spain
}

Corresponding author: Eduardo Fernández-Pascual; Telephone: +44 (0)1444894184; Fax: +44 (0)1444 894110; email: e.fernandezpascual@kew.org

This is a pre-copyedited, author-produced PDF of an article accepted for publication in Aquatic Botany following peer review. The version of record (Fernández-Pascual, E. (2016). Comparative seed germination traits in bog and fen mire wetlands. Aquatic Botany, 130, 21-26) is available online at: http://dx.doi.org/10.1016/j.aquabot.2016.01.001

\begin{abstract}
Mires are continental wetlands of high scientific and conservation interest. Understanding the seed germination traits of mire species is essential for comprehending their regeneration ecology and conducting active restoration policies. Here, a comparative study of seed germination traits was performed with 34 plant species from bog and fen communities, including many of the European indicators of these habitats. Freshly collected seeds were exposed to a laboratory germination experiment designed to characterize their response to (1) cold stratification and (2) simulated field temperatures. Germination strategy groups were interpreted according to these responses, and the relation between these groups and different mire types was discussed. Seeds of all tested species had physiological dormancy. Most of them showed conditional type 2 non-deep physiological dormancy: fresh seeds could germinate only at warm temperature, but attained the ability to germinate at colder temperature as they lost dormancy. Most mire species from bogs, poor fens and base-rich fens followed a warm germination strategy analogous to that of other wetland species. Species from this warm group responded to very warm temperatures which rarely occur in the field, and this was interpreted as a gap-detecting mechanism. In contrast, species from calcareous springs and flushes had a cold germination strategy, which would fit with the cold and stable soils where they occur. Finally, a group of species associated with the pioneer Rhynchosporion vegetation of bare peat areas have very low germination, suggesting an intermediate or deep seed dormancy and a long term seed bank.
\end{abstract}

Keywords: Arnica, Carex, dormancy, Drosera, Eleocharis, Eriophorum, European mire indicator, Narthecium, poor fen, regeneration strategy, Rhynchospora, Trichophorum

\section{Introduction}

A mire is a permanent semi-terrestrial wetland where soils remain waterlogged but not inundated during most of the year (Wheeler and Proctor, 2000). Mire classification is a rich field of study, with different criteria being emphasized in different academic and geographic contexts. Broadly, these communities are divided into rain-fed bogs and groundwater-fed fens; with fens further divided by their water and soil properties, derived from topology and the bedrock (Hájek et al., 2006). These mire types are also established according to indicator plant species that are strongly associated to each mire type (Wheeler and Proctor, 2000; Hájek et al., 2006). Generally, mires are regarded as habitats of high scientific and conservation interest. During the Quaternary, they provided refuge to wetland plants affected by climate change and human colonization (Jamrichová et al., 2014). At present, they hold a valuable biological diversity and are considered priority habitats for conservation in several parts of the world (e.g., Council Directive 92/43/EEC). Moreover, they are increasingly attracting attention as potential refugia against climate change (Raney et al., 2014; Fernández-Pascual et al., 2015a). At the same time, mires provide valuable ecosystem services, like regulating the water cycle and acting as carbon sinks (Bragg and Lindsay, 2003). Nevertheless, their conservation status is uncertain, with most European countries having lost more than half of their original mire surface (Bragg and Lindsay, 2003).

Active restoration policies require understanding the seed germination traits of mire species in order to benefit from seed collections conserved ex situ. The patchy distribution of mires favours short-distance dispersal and persistence through vegetative reproduction (Sosnova et al., 2010). Nonetheless, reproduction by seed is still essential for the colonization of new sites, the reoccupation of disturbed gaps and the long-term maintenance of mire species at the landscape level (Herben et al., 2014). As an example, massive germination of Rhynchospora fusca quickly occupies all safe niches following a disturbance, and subsequent propagation is mainly vegetative (Kesel and Urban, 1999). Similarly, seedling emergence patterns respond to microhabitat heterogeneity in Drosera intermedia (De Ridder and Dhondt, 1992) and Eriophorum vaginatum (Gartner et al., 1986). Although successful seedling establishment tends to be low (Gartner et al., 1986; De Ridder and Dhondt, 1992), mire seeds can remain viable at depths $(\mathrm{c} .50 \mathrm{~cm})$ that suggest very long-term seed 
banks (Jauhiainen, 1998). Thus, successful regeneration events by seed likely occur in long time scales. The importance of seed reproduction in detecting these 'opportunity gaps' is highlighted by several strategies that accelerate germination in special situations, such as pseudo-vivipary (Leck and Schütz, 2005), the response to extraordinary heat (Fernández-Pascual et al., 2013), and the effect of the diurnal thermal amplitude (Fernández-Pascual et al., 2015b).

Comparative community-wide assessments of mire germination traits are relatively scarce. Work has focused mainly on alkaline environments, such as mountain base-rich fens (Fernández-Pascual et al., 2013) and lowland fen grasslands (Maas, 1989; Patzelt et al., 2001; Jensen, 2004). Species from these habitats usually have conditional non-deep physiological dormancy (Baskin and Baskin, 2014) and follow a 'warm germination strategy' (Thompson and Grime, 1983). At the time of dispersal in autumn, they can germinate at very warm temperatures that rarely occur in the fen soils (Fernández-Pascual et al., 2015a). Subsequently, their temperature range for germination widens towards colder temperatures, either in the short term through increased diurnal thermal amplitudes (FernándezPascual et al., 2015b) or in the long term through overwintering (Fernández-Pascual et al., 2013). Such germination is common in the fen-dominant Carex genus (Schütz, 2000) and in Cyperaceae in general (Leck and Schütz, 2005). This 'warm strategy' has been proposed to detect changes in the water table (Thompson and Grime, 1983; Baskin and Baskin, 2014) and gaps opened by disturbances (Gartner et al., 1986; Fernández-Pascual et al., 2013). An alternative 'cool germination strategy' has been proposed for spring fen species that live close to water flushes, where soil temperatures are kept cold and stable throughout the year (Fernández-Pascual et al., 2013; Albrecht and Long, 2014).

Compared to base-rich fens, germination in bogs and poor fens has received less attention. Community-wide assessments have analysed emergence from the soil seed bank (Salonen, 1987; Jauhiainen, 1998) rather than germination requirements. Species-level studies indicate however that the 'warm germination strategy' might be prevalent also in bog and poor fen species; e.g. in Carex canescens (Schütz and Milberg, 1997), Eriophorum vaginatum (Wein and MacLean, 1973; Gartner et al., 1986) and Narthecium ossifragum (Summerfield, 1973).

The aim of our study was to conduct a comparative analysis of seed germination traits of European mire species. Such a comparative and community-wide assessment can be a useful contribution towards understanding the regeneration ecology of mires. To this end, we studied 21 species associated with bogs and poor fens, and analysed them together with previous work on an additional 13 base-rich fen species (FernándezPascual et al., 2013). Our specific research aims were to (1) test the germination response to treatments that simulate the natural thermal conditions; (2) group mire species according to their germination response; and (3) discuss the relation of these germination groups to specific mire types.

\section{Material and methods}

\subsection{Study system}

This study took place in the temperate oceanic region of north-western Spain $\left(43^{\circ} \mathrm{N}, 5^{\circ} \mathrm{W}\right)$. Local geography and climate are dominated by the Cantabrian Mountains (> $1500 \mathrm{~m}$ above sea level), that run parallel to the coast and trap the prevailing NW Atlantic winds. The resulting wet climate supports the south-western limit of mire communities in Europe (Jiménez-Alfaro et al., 2014). These communities encompass a wide variety of mire types, as defined in the EUNIS habitat classification (http://eunis.eea.europa.eu/habitats.jsp). Exclusively rain-fed blanket bogs (EUNIS code D1.2) are locally rare and occur on flat mountaintops close to the coast (Fernández Prieto et al., 1985). Acid valley mires (D2.11) can be found from the coast to just below the treeline, in poorly drained valleys and former glacial lake beds (Fernández Prieto et al., 1985). Glacial lakes undergoing silting develop transition mires and quaking bogs communities (D2.3) in the water-to-land transition (Martínez Cortizas et al., 2009). Spring fens appear in the mountains above $1000 \mathrm{~m}$, and they range from soft-water poor fens (D2.2) on acid bedrocks (Fernández Prieto et al., 1985) to base-rich and calcareous fens (D4) on limestone (Jiménez-Alfaro et al., 2012).

\subsection{Seed collection and germination}

Dispersal units (hereafter 'seeds') were collected from 53 accessions of 21 bog and poor fen species during 2012, 2013 and 2014 (Table 1). Sampling regularly covered the entire area of occupancy of the target populations and included all individuals bearing ripe seeds. After collection, seeds spent 3 weeks in the laboratory $\left(21^{\circ} \mathrm{C}\right.$, $50 \% \mathrm{RH})$ to ensure homogeneous maturation. Then, they were cleaned and the germination experiments started.

Laboratory germination experiments were conducted with seeds of all the species. For each experimental treatment, four Petri dishes holding $1 \%$ distilled water agar were prepared. As a standard, 25 seeds were sown in each Petri dish, but in some accessions with low seed numbers 15 or 20 seeds were sown instead (Table S1). During the experiments, the dishes were sealed with Parafilm to prevent desiccation. The experiment was fully factorial with two factors, pre-treatment and germination temperature. Pre-treatment had two levels: fresh seeds, incubated immediately after sowing; and cold-stratified seeds, which spent 12 weeks at $3{ }^{\circ} \mathrm{C}$ in 1 $\%$ agar and in darkness to simulate overwintering. Germination temperature had three levels or daily alternating regimes: $14 / 4{ }^{\circ} \mathrm{C}$ (autumn or spring); $22 / 12^{\circ} \mathrm{C}$ (summer); and $30 / 20{ }^{\circ} \mathrm{C}$ (unusual heat). Although the latter temperature regime rarely occurs in nature, it promotes germination in many fen species (FernándezPascual et al., 2013; Fernández-Pascual et al., 2015a). These germination temperatures were programmed 
inside incubators (Grow-S 360, Ing. Climas, Barcelona, Spain) and coupled to a $12 \mathrm{~h}$-light/12 h-darkness photoperiod (c. $20 \mu \mathrm{mol} \mathrm{m}-2 \mathrm{~s}-1$ during the light phase, provided by six Philips TLD30W/54-765 cool fluorescent tubes).

During incubation, germination was scored weekly as radicle emergence, and seedlings were removed. After the end of the experiments, non-germinated seeds were cut open and classified as apparently viable, empty and fungi infected. Germination percentages and further statistical analyses were calculated only with potentially germinable seeds (germinated + apparently viable, Table S1).

\subsection{Statistical analyses}

All statistical analyses were performed in R (v3.1.2, The $\mathrm{R}$ Foundation for Statistical Computing, Vienna, Austria). First, germination proportion data were analysed separately for each species using Generalised Linear Mixed Models (GLMM) with binomial error distribution and logit link function. Germination temperature $\left(14 / 4{ }^{\circ} \mathrm{C}, 22 / 12{ }^{\circ} \mathrm{C}\right.$ and $30 / 20{ }^{\circ} \mathrm{C}$ ), pretreatment and their interaction were included as fixed factors. Different seed accessions were included as a random factor. GLMMs were fitted separately for each species using the packages 'plyr' and 'lme4'. Some treatments that lacked variance (i.e., germination $=0$ or $100 \%$ ) had to be transformed (to germination $=1$ or 99 $\%$ ) so they could be included in the GLMMs, but the nontransformed values are shown in the figures. After model fitting, and to assess the significance of main effects and interactions, type III ANOVA tables (Table 2) were constructed using the package 'car'. The mean and $95 \%$ binomial confidence interval of each treatment were estimated using the package 'effects'.

Subsequently, a Principal Component Analysis (PCA) was used to reduce and visualize the variability in the species' seed germination traits (i.e., the estimated mean germination $\%$ at each of six experimental treatments described above, Table S2). This part of the analyses included the results of an earlier study in which the germination of an additional 13 species from base-rich fens was studied using the same experimental design (Fernández-Pascual et al., 2013). The PCA was computed with the package 'FactoMineR' using the variance-covariance matrix.

\section{Results}

Germination was variable among species. Carex panicea, C. pulicaris and Rhynchospora fusca did not germinate in any of the six treatments. Similarly, Carex binervis, $C$. flacca, C. nigra, C. rostrata, Drosera intermedia, Eleocharis multicaulis and Rhynchospora alba had very low germination percentages $(<20 \%$, Figure 1$)$. In the sedges (except for Carex panicea and C. pulicaris) this low germination was associated with very high percentages of empty seeds $(50-80 \%$, Table 1$)$. On the other hand, Arnica montana, Carex canescens, C. demissa, C. durieui, C. echinata, C. leporina, Drosera rotundifolia, Eriophorum angustifolium, E. vaginatum, Narthecium ossifragum and Trichophorum cespitosum all attained high germination percentages (Figure 1) and cold stratification significantly enhanced their germination (Table 2). In these species (except for Carex demissa), cold stratification also increased the germination temperature range, allowing species to germinate better at the lower temperatures (significant interaction effect in Table 2). With the exception of the low germinators listed above, the temperature regime significantly influenced germination (Table 2). Colder regimes promoted germination of only Carex leporina $\left(14 / 4{ }^{\circ} \mathrm{C}\right)$, Arnica montana $\left(22 / 12^{\circ} \mathrm{C}\right)$ and C. echinata $\left(22 / 12{ }^{\circ} \mathrm{C}\right)$. The other species germinated best at the highest temperature $\left(30 / 20^{\circ} \mathrm{C}\right)$, although seeds of Carex canescens, C. durieui, Eriophorum angustifolium, E. vaginatum and Narthecium ossifragum could also germinate well at $22 / 12^{\circ} \mathrm{C}$ (Figure 1).

The first two PCA axes (Figure 2) explained $85 \%$ of the variance in seed traits. Axis 1 (68 \% variance) was positively correlated with all germination traits (Pearson's $r>0.58$ ). This axis corresponded with overall germinability (or germination 'size'), separating those species with very poor results (e.g. Rhynchospora fusca) from those that germinated to high percentages across treatments (e.g. Eriophorum angustifolium) (Figure 1). On the other hand, axis 2 (16\% variance) correlated negatively with warm treatments; i.e. germination at $30 / 20{ }^{\circ} \mathrm{C}$ of fresh (Pearson's $\mathrm{r}<-0.32$ ) and cold-stratified seeds (Pearson's $r<-0.38$ ). At the same time, axis 2 correlated positively with the other, colder treatments; especially germination of cold-stratified seeds at $14 / 4^{\circ} \mathrm{C}$ (Pearson's $r>0.70$ ). Thus, axis 2 separated species that germinated better in low temperatures (e.g. Carex leporina) from those that responded better to high temperatures (e.g. Trichophorum cespitosum) (i.e., germination 'shape') (Figure 1).

\section{Discussion}

Optimal germination occurred at high temperatures $\left(30 / 20^{\circ} \mathrm{C}\right)$ in the majority of the bog and poor fen species that were examined here, similar to what we previously found for base-rich fens (Fernández-Pascual et al., 2013). These results support the idea that 'warm germination' is the typical strategy of mire species, as is the case in many wetland plants (Baskin and Baskin, 2014). Besides, all of the tested species had physiological seed dormancy at dispersal (Baskin and Baskin, 2014). Most of them were conditionally dormant, being able to germinate at high temperatures when fresh, and gaining the capacity to germinate at low temperatures after a season of cold stratification. Thus, seeds have type 2 non-deep physiological dormancy. However, a group of species had low or nil germination in all our treatments. Several of these species had healthy looking embryos (i.e., Carex panicea, C pulicaris, Drosera intermedia, Eleocharis multicaulis, Rhynchospora alba and Rh. fusca), suggesting that their low germination was the product of a deeper dormancy that we were not able to break. More northern seed collections of Carex flacca (Schütz, 1998; 
Schütz and Rave, 1999), C. nigra (Schütz and Rave, 1999) and Drosera intermedia (Crowder et al., 1990) attained high germination after long cold stratification periods (4-6 months). Even more so, Carex panicea still had low germination after 6 months of cold stratification (Schütz and Rave, 1999) and needed two seasons of overwintering to germinate (Jensen, 2004). At the same time, we must consider that in some of our sedges (i.e., Carex binervis, C. flacca, C. nigra and C. rostrata) low germination was accompanied by a high proportion of empty seeds. Since this occurred in all test collections, it might suggest a reproductive failure of the Cantabrian populations. However, all these species were collected in 2014, and more years of collecting would be necessary to confirm such an interpretation.

Our PCA ordination showed two main axes of variation in germination traits. The first one was overall germinability, and highlighted the aforementioned group of species with very low germination. Most of these were characteristic bog species of the Rhynchosporion bare peat depressions and mud-bottom hollows, i.e. Carex panicea, Eleocharis multicaulis, Drosera intermedia, Rhynchospora alba and Rh. fusca. This is a relatively ephemeral pioneer vegetation which colonises exposed peat after a perturbation (e.g. periodical changes of the water table or peat damage by humans, game or livestock); and which is quickly displaced by better competitors (i.e., shrub encroachment, taller Cyperaceae) in around a decade if no further perturbations occur (Stallegger, 2008). Therefore, these species may have an intermediate or deep dormancy (sensu Baskin and Baskin 2014) which is only broken by a signal associated to gap openings, and which ensures massive emergence after a perturbation (Kesel and Urban, 1999). Some potential signals could be nitrogen addition, immersion in water, soil drying or combined cycles of warm plus cold stratification (Baskin and Baskin, 2014). In any case, this specific germination strategy of the Rhynchosporion merits further research, especially considering the peculiar ecological niche and the conservation challenge of this community (Stallegger, 2008).

Focusing only on Carex, the germinability PCA axis seemed related to the phylogeny of the genus. Most of the studied taxa from subgenus Carex had low germinability (i.e., $\leq 20 \%$ in Carex binervis, C. flacca, C. nigra, C. panicea and C. rostrata). Of these species, the ones with the lowest germination $(\leq 6 \%$ in Carex binervis, C. flacca and C. panicea) are not exclusive to mires but can also occur in drier grasslands. Thus, their low germination percentages may reflect a deeper dormancy strategy associated with a more variable ecological niche than that of strict mire indicators. Also within subgenus Carex, more germination is shown by the mire specialists of section Ceratocystis, which groups the closely related taxa Carex demissa (maximum germination $=40 \%$ ) and Carex lepidocarpa $(53 \%)$; and the Spanish endemic Carex durieui (73\%), an indicator species of oceanic bogs and poor fens (Mayor and Carlón, 2001). The taxa at the other end of the germinability axis (i.e., $\geq 60 \%$ in Carex canescens, C. davalliana, C. diandra, C. echinata and C. leporina) all belong to subgenus Vignea. Carex pulicaris, the only species studied from subgenus Psyllophora had low germination in the treatments used here, but in a previous study (Fernández-Pascual et al., 2013) we found that unlike other Carex it responded better to warm than to cold stratification $\left(3\right.$ months at $\left.25^{\circ} \mathrm{C}\right)$.

The second PCA axis ordered species according to their optimal germination temperature. A group with higher germination at warm than at cold temperatures included species of base-rich fens (Blysmus compressus, Carex davalliana, Eriophorum latifolium and Swertia perennis) (Jiménez-Alfaro et al., 2014), transition mires and quaking bogs (Carex diandra) (Martínez Cortizas et al., 2009) and bogs and poor fens (Carex durieui, Narthecium ossifragum and Trichophorum cespitosum) (Fernández Prieto et al., 1985). These species follow closely the wetland warm germination strategy. Given the usual soil temperatures of Cantabrian fen soils (Fernández-Pascual et al., 2015a), these species would not germinate until summer and in special conditions of soil warming. On the other extreme of the axis, a second group of species germinated better at cold than at warm temperatures. These were the species identified as 'cold germinators' in our previous study (Fernández-Pascual et al., 2013), and the majority of them are associated to Cantabrian calcareous springs and flushes (Centaurium somedanum, Juncus alpinoarticulatus and Pinguicula grandiflora) (Jiménez-Alfaro et al., 2012). In the thermally stable soils close to the spring (Raney et al., 2014; Fernández-Pascual et al., 2015a), these species might germinate during spring and early summer. The case of Carex leporina, another cold germinator, should be interpreted with caution. Although the highest final germination percentages were after cold stratification and at $14 / 4{ }^{\circ} \mathrm{C}$, the seeds germinated during the last week of incubation. Therefore, it could be that 3 months of cold stratification were not enough to fully break dormancy, and further dormancy loss occurred at $14 / 4{ }^{\circ} \mathrm{C}$. A third group of species with a wide germination niche, which could germinate well at all temperatures, included plants that are exclusive of bogs and poor fens (Arnica montana, Eriophorum angustifolium, E. vaginatum, Carex canescens) and base-rich fens (Primula farinosa, Triglochin palustris), as well as species with a wide presence in the fen gradient (Carex echinata, Parnassia palustris). These species would germinate mostly during spring, but autumn germination could potentially occur in extraordinarily warm situations, such as dried soil patches.

It seems that mire specialist species share a common germination strategy analogous to most wetland species, with optimal germination at warm temperatures. While some of these species had a strong requirement for high temperatures, others also could germinate well at low temperatures. This strategy seems to be present in most mire types. A more specific 'cold germination strategy' was shown by spring specialists, while a deep dormancy 
seems to be prevalent in pioneer species of the Rhynchosporion. We suggest to focus future research in these two latter groups, to increase our understanding of the regeneration ecology of mire plant communities.

\section{Acknowledgements}

N. Martínez Vázquez and J.A. Prieto Domínguez provided invaluable help with field work and germination experiments. I also wish to thank Á. Balda Jáuregui, Á. Bueno Sánchez, L. Carlón Ruiz, M. Collado Prieto, V. García Díaz, T. García Gutiérrez, S. Iglesias Hernández and A. Piñán Gargantiel for their participation in seed collection campaigns. Two anonymous reviewers provided valuable comments to the manuscript. Seed collection was partly supported by the LIFE+ programme of the European Commission (project LIFE 11/NAT/ES/707 - TREMEDAL). I had the financial support of the Government of Asturias and the FP7 - Marie Curie - COFUND programme of the European Commission (Grant 'Clarín' ACA14-19). The Royal Botanic Gardens, Kew receives grant-in-aid from Defra.

\section{References}

Albrecht, M.A., Long, Q.G., 2014. Germination niche of the permanent wetland specialist, Parnassia grandifolia DC. Seed Sci. Res. 24, 239-245.

Baskin, C.C., Baskin, J.M., 2014, Seeds. Ecology, Biogeography and Evolution of Dormancy and Germination. Academic Press, San Diego.

Bragg, O., Lindsay, R., 2003, Strategy and action plan for mire and peatland conservation in Central Europe. Wetlands International, Wageningen.

Crowder, A.A., Pearson, M.C., Grubb, P.J., Langlois, P.H., 1990. Drosera L. J. Ecol. 78, 233-267.

De Ridder, F., Dhondt, A.A., 1992. The demography of a clonal herbaceous perennial plant, the longleaved sundew Drosera intermedia, in different heathland habitats. Ecography, 129-143.

Fernández-Pascual, E., Jiménez-Alfaro, B., Díaz, T.E., 2013. The temperature dimension of the seed germination niche in fen wetlands. Plant Ecol. 214, 489-499.

Fernández-Pascual, E., Jiménez-Alfaro, B., Hájek, M., Díaz, T.E., Pritchard, H.W., 2015a. Soil thermal buffer and regeneration niche may favour calcareous fen resilience to climate change. Folia Geobot. 50, 293-301.

Fernández-Pascual, E., Seal, C.E., Pritchard, H.W., 2015b. Simulating the germination response to diurnally alternating temperatures under climate change scenarios: comparative studies on Carex diandra seeds. Ann. Bot. 115, 201-209.

Fernández Prieto, J.A., Fernández Ordóñez, M.d.C., Collado Prieto, M.Á., 1985. Datos sobre la vegetación de las" turberas de esfagnos" galaico-asturianas y orocantábricas. Lazaroa 7, 443-471.

Gartner, B.L., Chapin III, F.S., Shaverm, G.R., 1986. Reproduction of Eriophorum vaginatum by seed in Alaskan tussock tundra. J. Ecol. $74,1-18$.

Hájek, M., Horsák, M., Hájková, P., Díte, D., 2006. Habitat diversity of Central European fens in relation to environmental gradients and an effort to standardise fen terminology in ecological studies. Perspect. Plant Ecol. Evol. Syst. 8, 97-114.

Herben, T., Nováková, Z., Klimešová, J., 2014. Clonal growth and plant species abundance. Ann. Bot. 114, 377-388.

Jamrichová, E., Hájková, P., Horsák, M., Rybníčková, E., Lacina, A., Hájek, M., 2014. Landscape history, calcareous fen development and historical events in the Slovak Eastern Carpathians. Veg. His. Archaeobot. 23, 497-513.

Jauhiainen, S., 1998. Seed and spore banks of two boreal mires. Ann. Bot. Fenn. 35, 197-201.
Jensen, K., 2004. Dormancy patterns, germination ecology, and seedbank types of twenty temperate fen grassland species. Wetlands 24, 152-166

Jiménez-Alfaro, B., Fernández-Pascual, E., Díaz González, T., PérezHaase, A., Ninot, J., 2012. Diversity of rich fen vegetation and related plant specialists in mountain refugia of the Iberian Peninsula. Folia Geobot. 47, 403-419.

Jiménez-Alfaro, B., Hájek, M., Ejrnaes, R., Rodwell, J., Pawlikowski, P., Weeda, E.J., Laitinen, J., Moen, A., Bergamini, A., Aunina, L., Sekulová, L., Tahvanainen, T., Gillet, F., Jandt, U., Dítě, D., Hájková, P., Corriol, G., Kondelin, H., Díaz, T.E., 2014. Biogeographic patterns of base-rich fen vegetation across Europe. Appl. Veg. Sci. 17, 367-380.

Kesel, R., Urban, K., 1999. Population dynamics of Gentiana pneumonanthe and Rhynchospora fusca during wet heathland restoration. Appl. Veg. Sci. 2, 149-156.

Leck, M.A., Schütz, W., 2005. Regeneration of Cyperaceae, with particular reference to seed ecology and seed banks. Perspect. Plant Ecol. Evol. Syst. 7, 95-133.

Maas, D., 1989. Germination characteristics of some plant species from calcareous fens in southern Germany and their implications for the seed bank. Holarctic Ecol. 12, 337-344.

Martínez Cortizas, A., Pontevedra Pombal, X., Nóvoa Muñoz, J.C., Rodríguez Fernández, R., López Sáez, J.A., Ferro Vázquez, C., Costa-Casais, M., Rodríguez Racedo, J., 2009, 7140 Mires de transición (Tremedales). In: Bermejo Bermejo, E., Melado Morillo, F. (Eds.), Bases ecológicas preliminares para la conservación de los tipos de hábitat de interés comunitario en España. Ministerio de Medio Ambiente, y Medio Rural y Marino, Madrid, pp. 1-34.

Mayor, M., Carlón, L., 2001. Distribución geográfica y comportamiento ecológico de Carex durieui Steud. ex Kunze y Myrica gale L. en Asturias. Boletín de Ciencias de la Naturaleza del RIDEA, 1-12.

Patzelt, A., Wild, U., Pfadenhauer, J., 2001. Restoration of wet fen meadows by topsoil removal: vegetation development and germination biology of fen species. Restor. Ecol. 9, 127-136.

Raney, P., Fridley, J., Leopold, D., 2014. Characterizing microclimate and plant community variation in wetlands. Wetlands $34,43-53$

Salonen, V., 1987. Relationship between the seed rain and the establishment of vegetation in two areas abandoned after peat harvesting. Holarctic Ecol. 10, 171-174.

Schütz, W., 1998. Seed dormancy cycles and germination phenologies in sedges (Carex) from various habitats. Wetlands 18, 288-297.

Schütz, W., 2000. Ecology of seed dormancy and germination in sedges (Carex). Perspect. Plant Ecol. Evol. Syst. 3, 67-89.

Schütz, W., Milberg, P., 1997. Seed dormancy in Carex canescens: regional differences and ecological consequences. Oikos, 420-428.

Schütz, W., Rave, G., 1999. The effect of cold stratification and light on the seed germination of temperate sedges (Carex) from various habitats and implications for regenerative strategies. Plant Ecol. $144,215-230$

Sosnova, M., van Diggelen, R., Klimešova, J., 2010. Distribution of clonal growth forms in wetlands. Aquat. Bot. 92, 33-39.

Stallegger, M., 2008, Management of Natura 2000 habitats. 7150 Depressions on peat substrates of the Rhynchosporion. European Commission, Technical Report 2008 19/24, Brussels.

Summerfield, R., 1973. Factors affecting the germination and seedling establishment of Narthecium ossifragum on mire ecosystems. J. Ecol., 387-398.

Thompson, K., Grime, J.P., 1983. A comparative study of germination responses to diurnally-fluctuating temperatures. J. Appl. Ecol. 20, 141-146.

Wein, R.W., MacLean, D., 1973. Cotton grass (Eriophorum vaginatum) germination requirements and colonizing potential in the Arctic. Can. J. Botany 51, 2509-2513.

Wheeler, B.D., Proctor, M.C.F., 2000. Ecological gradients, subdivisions and terminology of north-west European mires. J. Ecol. 88, 187-203. 
Fernández-Pascual (2016) Seed germination of mire plants

Table 1 Seeds collected for this study. Collection codes are those used in the database of the Seed Bank of the Jardín Botánico Atlántico (Xixón, Spain), where the seeds are kept. The first six numbers of each code indicate the seed collection date in the format ddmmyy. $\mathrm{pH}$ and conductivity values are the average of 2-10 measures per site (depending on mire area) taken with a MM40 Portable Multimeter (Crison Instruments S.A., Alella, Spain). The percentages of empty and fungi infected seeds are provided.

\begin{tabular}{|c|c|c|c|c|c|c|c|c|}
\hline Species & Collection & Site & UTM (ED50) & Altitude (m) & $\mathrm{pH}$ & Conductivity $(\mu \mathrm{S} / \mathrm{cm})$ & Empty (\%) & Infected (\%) \\
\hline Arnica montana & $300714-01$ & Las Dueñas & 29T 7286604827320 & 120 & 4.4 & 64.3 & 18 & 9 \\
\hline Arnica montana & $310714-03$ & Comeya & 30T 3386404794570 & 840 & 6.8 & 189.8 & 14 & 4 \\
\hline Carex binervis & 030714-01 & Las Muelles & 29T 7164104806910 & 650 & 5.5 & 62.2 & 72 & 3 \\
\hline Carex binervis & $060814-56$ & Los Carros & 30T 3154904772040 & 1500 & 4.9 & 16.3 & 37 & 13 \\
\hline Carex canescens & $060814-61$ & El Cable & 30T 3419304774510 & 1680 & 6.6 & 112.8 & 5 & 2 \\
\hline Carex canescens & $070814-51$ & Reconcos & 29T 7030804764070 & 1630 & 4.5 & 27.7 & 29 & 4 \\
\hline Carex canescens & $070814-53$ & Llouchinas & 29T 7046904763230 & 1550 & 5.0 & 19.6 & 24 & 4 \\
\hline Carex demissa & $060814-54$ & Los Carros & 30T 3154904772040 & 1500 & 4.9 & 16.3 & 16 & 4 \\
\hline Carex demissa & 310714-04 & Comeya & 30T 3386404794570 & 840 & 6.8 & 189.8 & 28 & 9 \\
\hline Carex durieui & 030714-02 & Las Muelles & 29T 7164104806910 & 650 & 5.5 & 62.2 & 6 & 7 \\
\hline Carex durieui & 130814-04 & Las Penas & 29T 7178804801170 & 710 & - & - & 45 & 8 \\
\hline Carex durieui & $300714-02$ & Las Dueñas & 29T 7286604827320 & 120 & 4.4 & 64.3 & 40 & 3 \\
\hline Carex echinata & 030714-03 & Las Muelles & 29T 7164104806910 & 650 & 5.5 & 62.2 & 43 & 1 \\
\hline Carex echinata & 070714-10 & El Pinar de Lillo & 30T 3159404770263 & 1420 & 4.5 & 16.8 & 19 & 2 \\
\hline Carex echinata & 070714-16 & La Brañuela & 30T 3145304770380 & 1300 & 6.0 & 105.9 & 14 & 1 \\
\hline Carex echinata & $180712-20$ & Los Piélagos & 29T 7272304791530 & 1030 & 7.2 & 562.5 & 4 & 1 \\
\hline Carex echinata & $260614-03$ & Comeya & 30T 3386404794570 & 840 & 6.8 & 189.8 & 5 & 3 \\
\hline Carex flacca & 030714-06 & Las Muelles & 29T 7164104806910 & 650 & 5.5 & 62.2 & 53 & 10 \\
\hline Carex flacca & 070714-17 & La Brañuela & 30T 3145304770380 & 1300 & 6.0 & 105.9 & 53 & 2 \\
\hline Carex flacca & $300714-04$ & Las Dueñas & 29T 7286604827320 & 120 & 4.4 & 64.3 & 81 & 4 \\
\hline Carex leporina & $060814-53$ & Valdecarrín & 30T 3175204771700 & 1640 & 5.7 & 21.2 & 10 & 5 \\
\hline Carex leporina & $060814-60$ & El Cable & 30T 3419304774510 & 1680 & 6.6 & 112.8 & 5 & 4 \\
\hline Carex nigra & $060814-52$ & Valdecarrín & 30T 3175204771700 & 1640 & 5.7 & 21.2 & 69 & 10 \\
\hline Carex nigra & $060814-55$ & Los Carros & 30T 3154904772040 & 1500 & 4.9 & 16.3 & 70 & 22 \\
\hline Carex nigra & $070814-50$ & Reconcos & 29T 7030804764070 & 1630 & 4.5 & 27.7 & 85 & 7 \\
\hline Carex nigra & $070814-52$ & Llouchinas & 29T 7046904763230 & 1550 & 5.0 & 19.6 & 80 & 12 \\
\hline Carex panicea & $060814-63$ & El Cable & 30T 3419304774510 & 1680 & 6.6 & 112.8 & 7 & 23 \\
\hline Carex pulicaris & 030714-04 & Las Muelles & $29 \mathrm{~T} 7164104806910$ & 650 & 5.5 & 62.2 & 3 & 1 \\
\hline Carex pulicaris & 070714-15 & La Brañuela & 30T 3145304770380 & 1300 & 6.0 & 105.9 & 14 & 4 \\
\hline
\end{tabular}

(Continues) 
Fernández-Pascual (2016) Seed germination of mire plants

\begin{tabular}{|c|c|c|c|c|c|c|c|c|}
\hline \multicolumn{9}{|c|}{ (Continues) } \\
\hline Species & Collection & Site & UTM (ED50) & Altitude (m) & $\mathrm{pH}$ & Conductivity $(\mu \mathrm{S} / \mathrm{cm})$ & Empty (\%) & Infected $(\%)$ \\
\hline Carex rostrata & 110814-04 & La Recoleta & 29T 7354604766860 & 1780 & 7.2 & 245.9 & 49 & 4 \\
\hline Carex rostrata & $310714-05$ & Comeya & 30T 3386404794570 & 840 & 6.8 & 189.8 & 82 & 4 \\
\hline Drosera intermedia & 011013-01 & Comeya & 30T 3386404794570 & 840 & 6.8 & 189.8 & 0 & 0 \\
\hline Drosera intermedia & 160914-07 & Los Cándanos & 30T 3660404805150 & 220 & 3.0 & 87.1 & 12 & 12 \\
\hline Drosera rotundifolia & 060913-02 & Los Cándanos & 30T 3660404805150 & 220 & 3.0 & 87.1 & 4 & 7 \\
\hline Drosera rotundifolia & 160914-06 & Los Cándanos & 30T 3660404805150 & 220 & 3.0 & 87.1 & 13 & 12 \\
\hline Drosera rotundifolia & 170913-08 & La Veiga Cimera & 29T 7237604767370 & 1570 & 4.6 & 13.9 & 1 & 1 \\
\hline Eleocharis multicaulis & 190614-07 & Peñes & 30T 2701004837670 & 100 & 4.7 & 175.9 & 5 & 2 \\
\hline Eleocharis multicaulis & $310714-01$ & Comeya & 30T 3386404794570 & 840 & 6.8 & 189.8 & 10 & 7 \\
\hline Eriophorum angustifolium & 050614-08 & El Molinucu & 30T 2948304807660 & 300 & 4.2 & 47.2 & 22 & 13 \\
\hline Eriophorum angustifolium & $100712-03$ & La Veiga Cimera & 29T 7237604767370 & 1570 & 4.6 & 13.9 & 59 & 10 \\
\hline Eriophorum angustifolium & $120614-14$ & Comeya & 30T 3386404794570 & 840 & 6.8 & 189.8 & 13 & 12 \\
\hline Eriophorum angustifolium & $120712-17$ & Los Cándanos & $30 \mathrm{~T} 3660404805150$ & 220 & 3.0 & 87.1 & 46 & 1 \\
\hline Eriophorum vaginatum & 070714-07 & El Pinar de Lillo & 30T 3159404770263 & 1420 & 4.5 & 16.8 & 20 & 3 \\
\hline Eriophorum vaginatum & 070714-19 & Los Carros & 30T 3154904772040 & 1500 & 4.9 & 16.3 & 52 & 2 \\
\hline Eriophorum vaginatum & $230712-02$ & La Venta & 30T 3086504775310 & 1650 & 4.3 & 10.6 & 15 & 4 \\
\hline Eriophorum vaginatum & $230712-06$ & La Cárbaza & 30T 3090804775420 & 1510 & 4.5 & 17.3 & 34 & 8 \\
\hline Narthecium ossifragum & $160914-02$ & Los Carriles & 30T 3453004809570 & 220 & 3.4 & 46.1 & 14 & 15 \\
\hline Narthecium ossifragum & $160914-08$ & Los Cándanos & 30T 3660404805150 & 220 & 3.0 & 87.1 & 10 & 15 \\
\hline Rhynchospora alba & $160914-05$ & Los Cándanos & 30T 3660404805150 & 220 & 3.0 & 87.1 & 15 & 9 \\
\hline Rhynchospora fusca & $170914-01$ & Maulitx & 30T 6242704777460 & 650 & - & - & 10 & 4 \\
\hline Rhynchospora fusca & $170914-03$ & Arxuri & 30T 6174004790180 & 530 & - & - & 10 & 8 \\
\hline Trichophorum cespitosum & $060814-57$ & Los Carros & 30T 3154904772040 & 1500 & 4.9 & 16.3 & 9 & 7 \\
\hline Trichophorum cespitosum & $180614-15$ & Los Carriles & 30T 3453004809570 & 220 & 3.4 & 46.1 & 3 & 3 \\
\hline
\end{tabular}


Table 2 Generalised Linear Mixed Models (GLMM) fitted to the results of the factorial chilling x germination temperature experiments. GLMM had binomial error distribution and logit link, and included seed collection as a random factor. No models were fitted for $\mathrm{C}$. panicea, $\mathrm{C}$. pulicaris and $\mathrm{Rh}$. fusca because none of their seeds germinated. The table is a type III ANOVA calculated using Wald's $\chi 2$; except for Rhynchospora alba, which had only one collection and for which nonmixed GLM was used and $\chi 2$ is the Likelihood Ratio. Significant parameters $(\mathrm{p}<0.05)$ are bolded.

\begin{tabular}{|c|c|c|c|c|c|c|}
\hline \multirow{2}{*}{ Species } & \multicolumn{2}{|c|}{ Interaction } & \multicolumn{2}{|c|}{ Chilling } & \multicolumn{2}{|c|}{ Temperature } \\
\hline & $\chi^{2}(2)$ & $\mathrm{p}$ & $\chi^{2}(1)$ & $\mathrm{p}$ & $\chi^{2}(2)$ & $\mathrm{p}$ \\
\hline Arnica montana & 37.819 & $<0.001$ & 176.837 & $<0.001$ & 75.549 & $<0.001$ \\
\hline Carex binervis & 0.010 & 0.995 & 0.010 & 0.922 & 0.019 & 0.991 \\
\hline Carex canescens & 36.608 & $<0.001$ & 101.735 & $<0.001$ & 125.814 & $<0.001$ \\
\hline Carex demissa & 5.659 & 0.059 & 13.914 & $<0.001$ & 33.348 & $<0.001$ \\
\hline Carex durieui & 26.728 & $<0.001$ & 60.377 & $<0.001$ & 68.908 & $<0.001$ \\
\hline Carex echinata & 42.232 & $<0.001$ & 381.988 & $<0.001$ & 150.527 & $<0.001$ \\
\hline Carex flacca & 0.524 & 0.769 & 0.173 & 0.677 & 0.449 & 0.799 \\
\hline Carex leporina & 32.054 & $<0.001$ & 84.108 & $<0.001$ & 1.267 & 0.531 \\
\hline Carex nigra & 0.329 & 0.848 & 0.002 & 0.964 & 0.232 & 0.891 \\
\hline Carex rostrata & 0.750 & 0.687 & 0.559 & 0.455 & 0.707 & 0.702 \\
\hline Drosera intermedia & 0.133 & 0.936 & 0.044 & 0.834 & 1.095 & 0.578 \\
\hline Drosera rotundifolia & 32.391 & $<0.001$ & 75.705 & $<0.001$ & 32.241 & $<0.001$ \\
\hline Eleocharis multicaulis & 4.295 & 0.117 & 7.913 & 0.005 & 4.258 & 0.119 \\
\hline Eriophorum angustifolium & 68.267 & $<0.001$ & 1.291 & 0.256 & 170.939 & $<0.001$ \\
\hline Eriophorum vaginatum & 81.004 & $<0.001$ & 0.008 & 0.929 & 340.192 & $<0.001$ \\
\hline Narthecium ossifragum & 34.604 & $<0.001$ & 86.745 & $<0.001$ & 68.938 & $<0.001$ \\
\hline Rhynchospora alba & 2.536 & 0.281 & 2.936 & 0.087 & 2.136 & 0.344 \\
\hline Trichophorum cespitosum & 25.449 & $<0.001$ & 28.776 & $<0.001$ & 93.437 & $<0.001$ \\
\hline
\end{tabular}




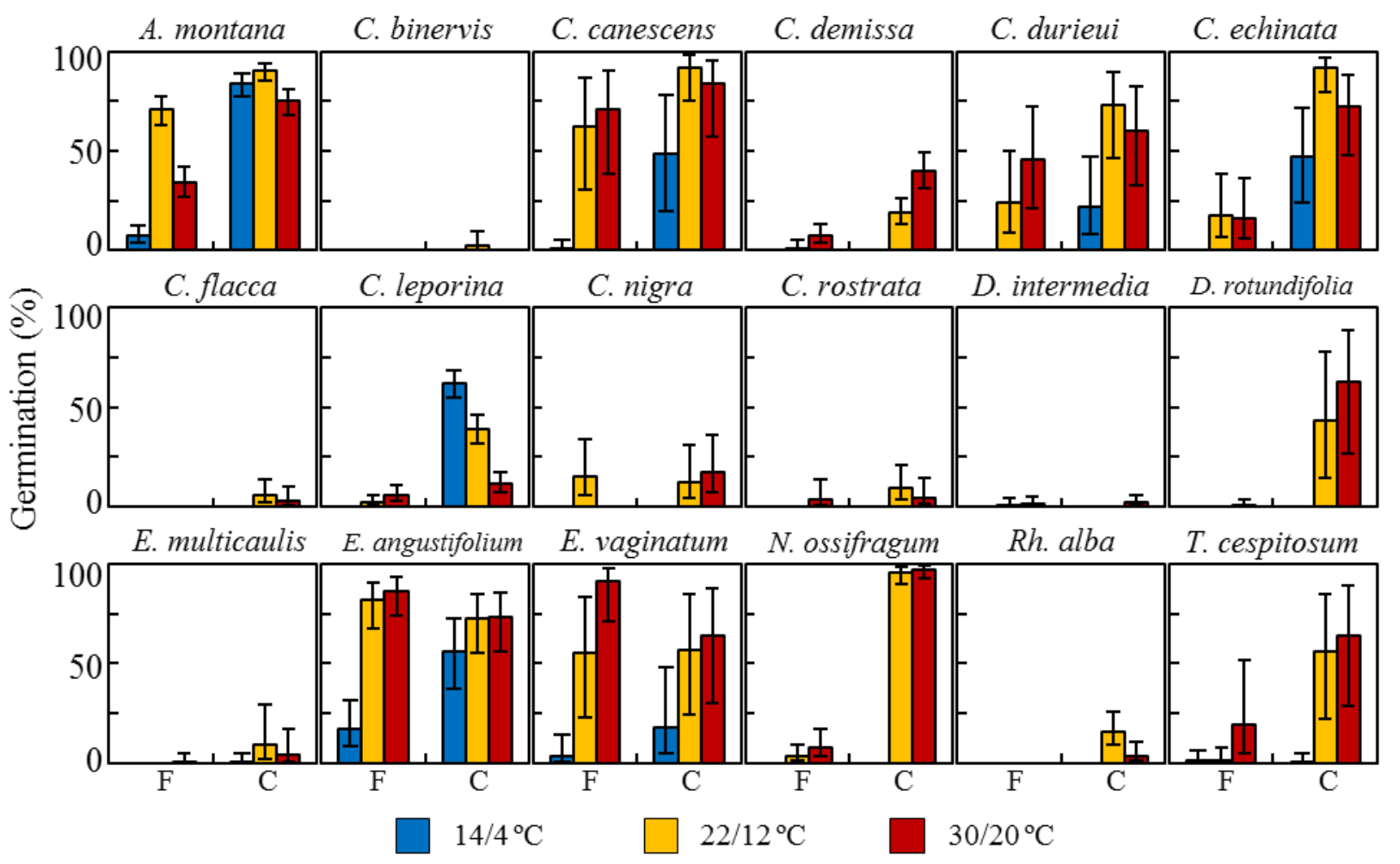

Figure 1 Final germination at three thermoperiods of fresh (F) or cold-stratified (C) seeds. Results were estimated by Generalised Linear Mixed Models (binomial distribution, logit link). Bars represent means, brackets the $95 \%$ binomial confidence interval. No seeds germinated in C. panicea, C. pulicaris and Rh. fusca and thus they are not represented. 


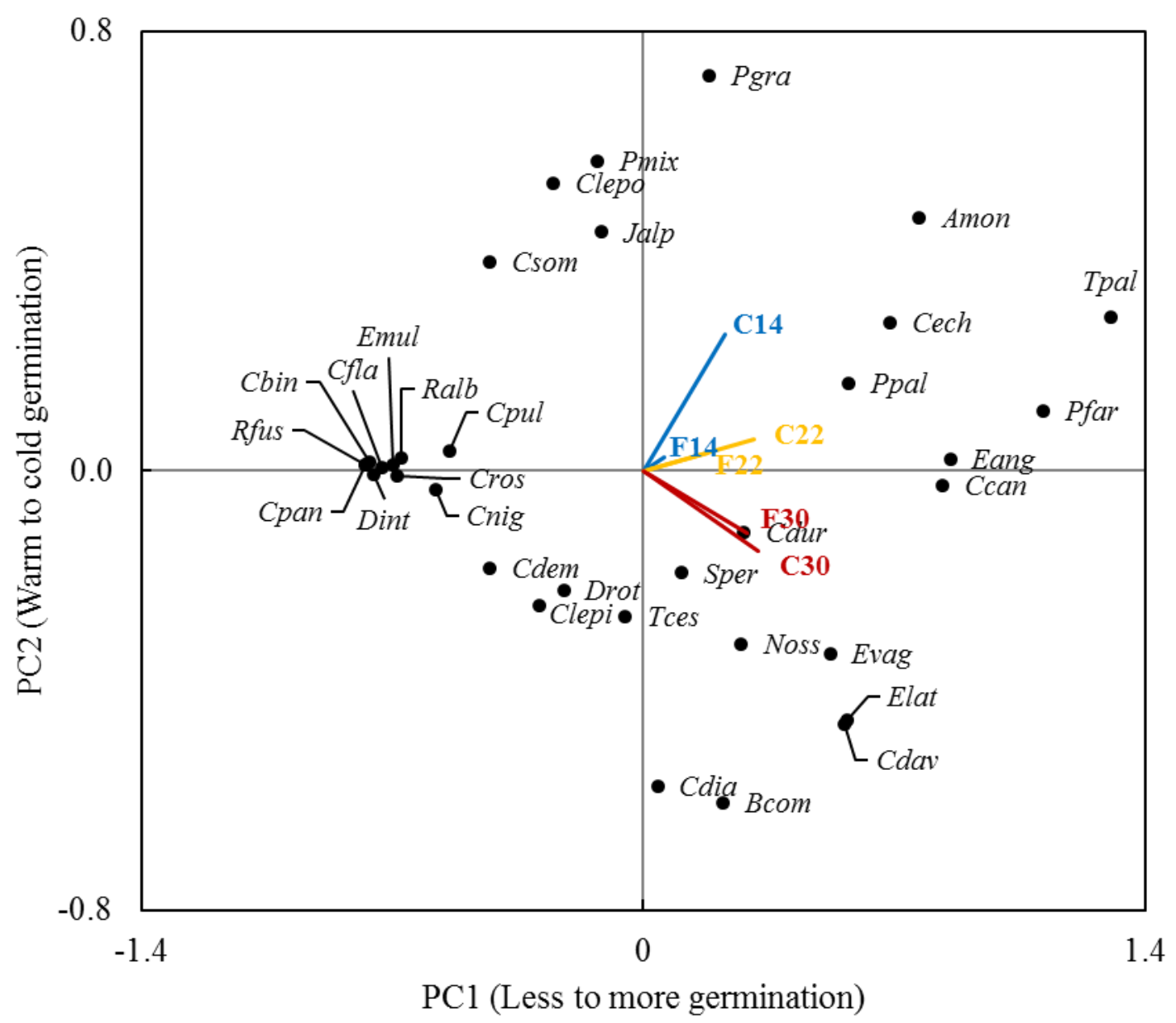

Figure 2 Principal Component Analysis ordination of the variation in germination traits. For each species, germination behaviour was characterized by 6 traits. Each trait was the average germination percentage of a species in each of six treatments: fresh $(=\mathrm{F})$ and cold-stratified $(=\mathrm{C})$ seeds germinated at either $14 / 4(=14), 22 / 12(=22)$ or $30 / 20(=22){ }^{\circ} \mathrm{C}$. The first two principal axes, represented here, explained $85 \%$ of the variation in germination traits. Axis 1 correlated positively with all germination traits. Axis 2 correlated negatively with warm traits; and positively with cold traits. Points represent the position of each species in the two principal axes. Each species is abbreviated to the first letter of the genus and the first three letters of the specific epithet. Vectors represent the contribution of each germination trait to the two principal axes. 